\title{
Effects of Covid-19 outbreak on environment and renewable energy sector
}

\author{
Hasan Eroğlu ${ }^{1}$ \\ Received: 21 April 2020 / Accepted: 19 June 2020 / Published online: 28 June 2020 \\ (c) Springer Nature B.V. 2020
}

\begin{abstract}
Many articles have been written in the medical field related to the Covid-19 outbreak that has surrounded the World and killed many people. However, its environmental and energy impacts have not been sufficiently studied. Some sources argue that Covid-19 outbreak reduces pollution environmentally, while others say that environmentally significant damages await us. On the other hand, it is wondered how the global flexible renewable energy sector will react to Covid-19 outbreak. In this study, the effects of Covid-19 outbreak in terms of the environment and renewable energy sector in the literature were examined in detail and the findings obtained were discussed. The main aim of this study is to shed light on the future studies of environmental and renewable energy researchers.
\end{abstract}

Keywords Covid-19 outbreak · Environment · Renewable energy sector

\section{Introduction}

Coronavirus Disease 2019 (Covid-19) outbreak emerged in Wuhan, China, whose spreading dynamics is not fully understood (Huang et al. 2020; Zeng et al. 2020), increased in a very short time and was declared as a pandemic by the World Health Organization (WHO) on March 11, 2020. It is reported that with serious measures taken, the outbreak in China has decreased (Gautam and Hens 2020). However, as of April 22, worldwide, 2.546.527 confirmed cases and 175.621 confirmed deaths were reported by WHO (2020a). The most prominent feature of the virus is its rapid spread and long incubation period (Linton et al. 2020; Qian et al. 2020; Wilder-Smith and Freedman 2020). It is known that the virus does not have a direct impact on the environment and energy sector individually. However, socially, situations arise that may indirectly affect the environment and energy sector. The effects of some successful and definitive measures taken by countries to prevent Covid-19 are just emerging. The effects of Covid-19 outbreak pandemic on human life have been started to be investigated from different angles. For example, during the Covid19 outbreak, the effects of house arrest on children and ways to mitigate these effects are

Hasan Eroğlu

hasan.eroglu@erdogan.edu.tr

1 Department of Electrical and Electronics Engineering, Recep Tayyip Erdogan University, Rize, Turkey 
investigated by Wang et al. (2020a). The effects of Covid-19 outbreak on household food wastage were investigated by Jribi et al. (2020). The effect of bio-aerosol on the spread of Covid-19 virus was investigated by Gautam and Trivedi (2020). In some studies (Conticini et al. 2020; Contini and Costabile 2020; Gautam 2020), the effects of atmospheric pollution on Covid-19 mortality were investigated, while in others (Sharma et al. 2020; Wang et al. 2020b), the effect of the Covid-19 outbreak on air pollution was investigated. Likewise, during the Covid-19 outbreak, changes in air quality in Barcelona (Spain) were examined (Tobías et al. 2020). With this general review in the literature, it is seen that there are very few studies on the effects of Covid-19 outbreak on the energy sector and the environment. With this study, the studies reported in the literature on the effects of Covid-19 outbreak on the renewable energy sector and the environment were examined, the importance of the subject was revealed, and future studies were shed light on. General contributions of the study can be listed as follows:

- It is presented that Covid-19 outbreak has serious environmental impacts such as increased environmental waste.

- Covid-19 outbreak provides a reduction in greenhouse gas emissions, but more efforts are needed to prevent air pollution.

- The capacity increase estimates for 2020 for wind energy are projected to decrease by $4.9 \mathrm{GW}$ and $28 \%$ in solar energy due to the outbreak.

- There are serious dismissals and discontinuities in the energy sector.

- In order to reduce the negative impact of the outbreak on the renewable energy sector, governments should urgently make the necessary interventions.

\section{Environmental effects of Covid-19 outbreak}

There are two situations in the studies examined about Covid-19 outbreak. These can be divided into two categories: Covid-19 outbreak's environmentally beneficial effects and environmentally hazardous effects. These effects are discussed in detail below.

\subsection{Harmful effects of Covid-19 outbreak to the environment}

Covid-19 outbreak pandemic, which restricts the daily mobility of people with its increasing effect worldwide, caused the closure of the factories, the stopping of education and training (Bandyopadhyay 2020), the halt of social mobility and the reduction in greenhouse gas emissions in industrial countries. Besides serious limitations in international travel, entertainment, sports, hospitality, tourism, transportation, manufacturing and many other sectors were also affected by the outbreak. The global aviation industry expects that they could damage \$ 100 billion due to such restrictions (Bandyopadhyay 2020; Doherty 2020). A study has been put forward by Yu and Aviso (2020) to assess the vulnerability caused by the outbreak at the international level in the supply chain. Such a wide outbreak pandemic, of course, has environmentally destructive effects. One of these is medical wastes resulting from the increased medical activity. It was stated that for the period when the outbreak peaked in Wuhan, an average of 240 tons of medical waste was produced daily in hospitals and this value was 6 times higher than normal value (Zuo 2020). Also, plastic-based medical masks used worldwide are an environmental problem. Tracey Read, founder of the non-plastic organization called "Seas Without Plastic" in Hong Kong, stated that masks are 
made of polypropylene, a type of plastic, and it is very difficult to get lost in nature (CDP 2020; Robert 2020). Medical masks collected from the sea by a group of environmentalists in China are shown in Fig. 1. It is reported as good news that there is no evidence yet that the Covid-19 virus is transmitted through wastewater or the sewage or water treatment workers would have been at risk of infection. Also, there is no evidence that Covid-19 is transmitted in any way through healthcare waste (WHO 2020b).

\subsection{The beneficial effects of Covid-19 outbreak on the environment}

Environmentally, the Covid-19 outbreak also has constructive effects. Studies started in the home environment during the outbreak increased Home Office applications. This will have an effect that will reduce carbon dioxide emissions by reducing the mobility of people in their external environment. Many countries in the world have switched to distance education due to corona virus (Zhou et al. 2020). Social mobility, which causes many carbon emissions, such as student services, has also decreased with distance education. In addition, since the scientific events, meetings and political events started to be held in the form of a remote conference, environmental emissions have decreased globally. In this context, those who are accustomed to the efficiency of teleconferencing and distance education are expected to increase the number of these activities after the outbreak (Rohwer-Kahlmann 2020). In most countries, there has been a lockdown with people not allowed to move around leading to a reduction in greenhouse gas emissions. In the course of the Covid-19 outbreak, the greenhouse gas emission reduction is observed during the restrictions of the states, such as China and Italy (CDP 2020). A reduction of approximately 25\% of carbon emission is reported in China (Myllyvirta 2020). It is also reported that air pollution (such as nitrogen dioxide and carbon dioxide emission) is reduced in many regions (McMahon 2020). Figure 2 shows the condition of nitrogen dioxide on France and Italy provided by The Copernicus Sentinel-5P satellite in the pandemic period and 1 year ago (ESA 2020; Muhammad et al. 2020). From Fig. 2b, c, it is reported that a minimum 10-day average is required to obtain a good

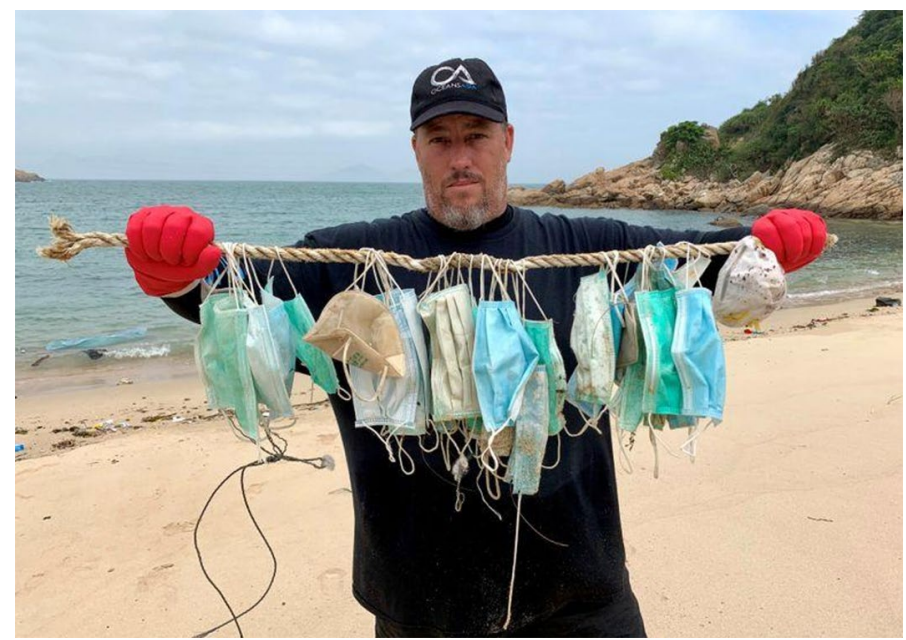

Fig. 1 Medical masks collected by some environmentalists from the sea in China (Robert 2020) 

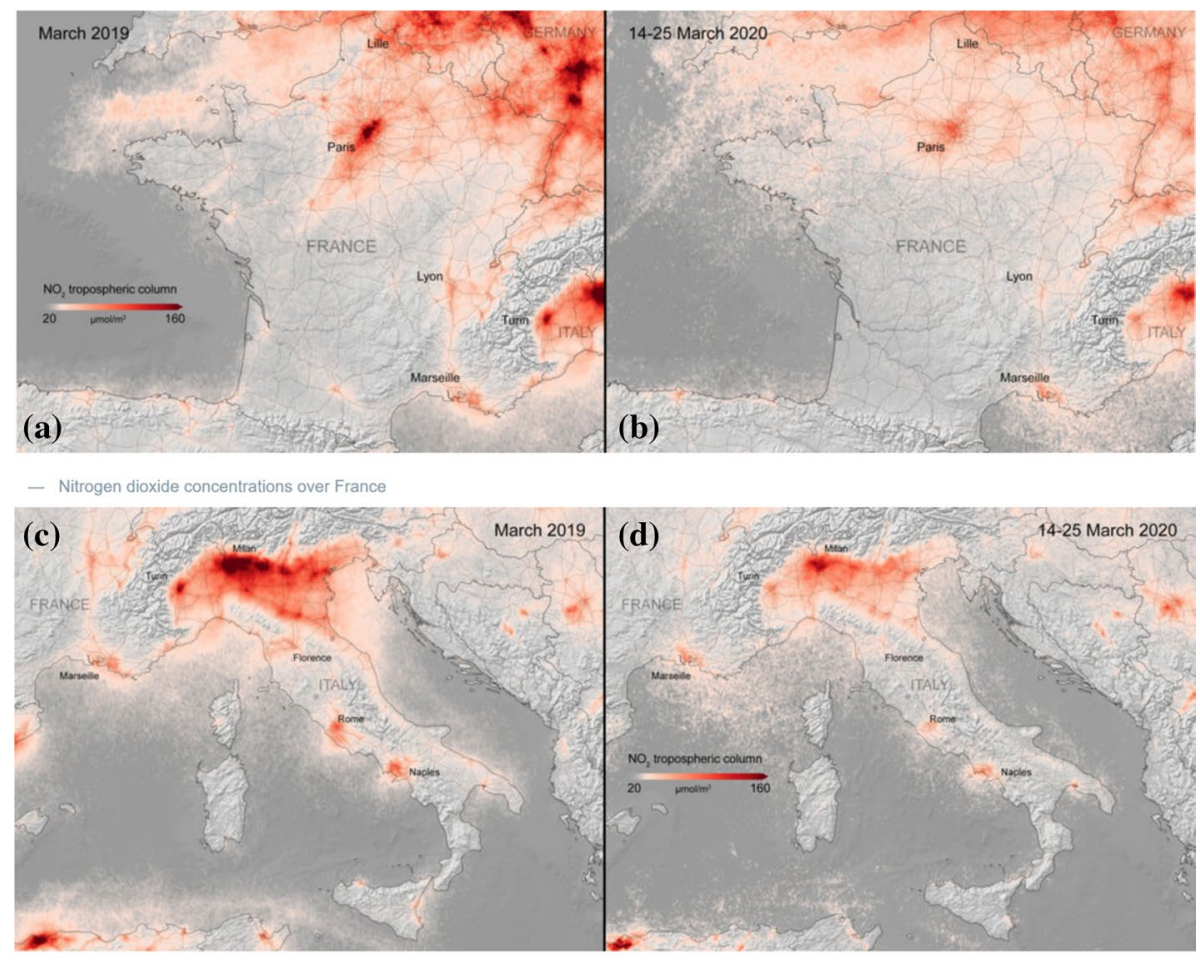

- Nitrogen dioxide concentrations over Italy

Fig. 2 Comparison of $\mathrm{NO}_{2}$ concentration on France $(\mathbf{a}, \mathbf{b})$ and Italy $(\mathbf{c}, \mathbf{d})$ before $(\mathbf{a}, \mathbf{c})$ and after $(\mathbf{b}, \mathbf{d})$ the Covid-19 outbreak pandemic (ESA 2020)

aerial image (Jonathan Amos 2020). Therefore, atmospheric pollution is observed to decrease during the Covid-19 outbreak (Watts and Kommenda 2020).

On the other hand, the reduction in concentrations of different pollutants in China is estimated by Wang et al. (2020b) with the Community Multi-Scale Air Quality Model. As a result of the study, it has been revealed that the decrease in transportation and industrial activities in China is not enough to prevent air pollution in cases when meteorology is unfavorable. Therefore, it was emphasized that more effort is required to achieve a serious reduction in air pollution. In another study (Tobías et al. 2020), it was revealed that there was a decrease in air pollution during the outbreak in Barcelona (Spain), but there were significant differences between the pollutants. It has been observed that the most important reduction amounts are in $\mathrm{BC}$ (black carbon) and $\mathrm{NO}_{2}$ (nitrogen dioxide), while a lower decrease occurs in PM10 (the particulate matter with a diameter of less than 10). In contrast, an increase in $\mathrm{O}_{3}$ (ozone) level (probably due to lower titration of $\mathrm{O}_{3}$ by $\mathrm{NO}$ ) has been reported. One reason for the less decline in PM10 compared to other gaseous pollutants like NO2 is the effect of natural additives such as sea spray and desert powder, which strongly affect Spain, Italy, Greece and the entire Mediterranean basin. It has been revealed that more in-depth analysis is required for the reasons for the decrease in PM10 (Conte et al. 2020).

In the study conducted by Jribi et al. (2020), it was revealed that individuals whose social activities were restricted during the Covid-19 outbreak were conscious of food 
waste, they tried to reduce waste, and they displayed behaviors to prevent food waste. According to another analysis conducted in the same study, it was revealed that the reason for avoiding food waste was the negative socioeconomic effects (food anxiety, limited movements, lack of income) of Covid-19 outbreak rather than environmental awareness. During this Covid-19 outbreak, it will be beneficial to intensify education and communication campaigns in order to increase environmental positive behaviors of people.

\section{The effects of Covid-19 outbreak on the renewable energy sector}

Another important effect of the Covid-19 outbreak is in the renewable energy sector. The industry is suffering due to problems such as delays in the supply chain, problems in tax stock markets and the risk of not being able to benefit from government incentives ending this year (Birol 2020). There is also a serious drop in energy demand due to the outbreak. Figure 3 shows the daily coal consumption of 6 main energy companies in China (Myllyvirta 2020). The curve, shown in red, shows that there has been a decrease in consumption from the beginning of 2020 compared to previous years.

On the other hand, clean energy and its spread were also affected by the outbreak. The first noticeable effect on the current situation; renewable energy investments; and incentives place in the second plan due to the large number of incentives put into practice by countries in the fight against the Covid-19 outbreak. At this point, governments are advised by the Executive Director of the International Energy Agency (Birol 2020) to increase their warranty and contract mechanisms to reduce financial risks, and this step will prevent investors from moving away from clean energy investments due to Covid-19 outbreak.

The outbreak has caused the sharpest decline of nearly 30 years globally, causing serious concern for companies. Covid-19 outbreak also has a devastating effect on the global

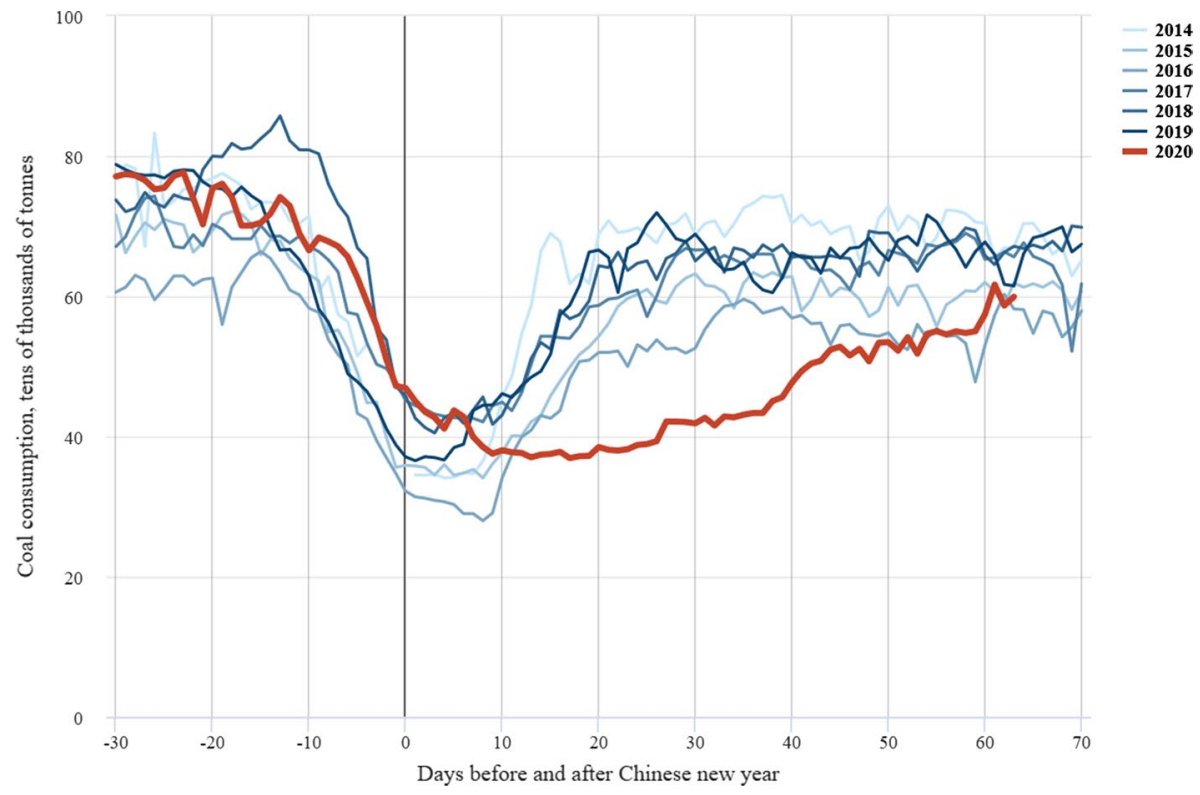

Fig. 3 Daily coal consumption at six major power firms of China (Myllyvirta 2020) 
renewable energy supply chain. If the incentives to be made are away from clean energy targets, it will be likely that there will be a serious reduction in clean energy investments and a domino effect (Emma 2020). For example, the predictions of the crisis have already started in wind energy. Accordingly, it is predicted that 2020 wind energy additions will decrease by 4.9 GW globally (David 2020). The spread of Covid-19 outbreak (110 confirmed cases) and closure of the facility (Anmar 2020) in a wind power plant in North Dakota are one of the main examples of the outbreak's effects on the renewable energy sector. LM Wind Power and Siemens Gamesa in Spain have announced that they have decided to stop their wind turbine blade plant production. In the Outer Moray Firth, it was stated that the installation of 100 wind turbines was interrupted due to the Covid-19 outbreak, and some parts in the delivery phase stopped (McPhee 2020).

The same situation is also true for the solar industry. Renewable energy estimates for 2020 decrease by $28 \%$ due to Covid-19 outbreak (SEIA 2020a). It is stated that the workers of the solar energy sector have been dismissed or suffered due to the Covid-19 outbreak. The results of a survey on the subject are given in Fig. 4. According to Fig. 4, 55\% of the sector workers participating in the survey have been dismissed or suffering (SEIA 2020b).

It is also stated in the same survey as general problems for the solar industry: construction delays (86\%), supply chain and equipment delays (84\%), permitted delays (81\%) and customer acquisition (81\%). In addition, the cancellation rate of solar energy systems in residential applications is $19 \%$ and the job delay rate is $53 \%$. In another study, the percentage of those who were laid off in the clean energy sector (Tim 2020) due to the outbreak in the USA is shown as in Fig. 5.

In order to overcome the mentioned problems, some suggestions are offered in the USA (SEIA 2020a) such as allowing solar companies to fully utilize Investment Tax Credit (ITC) and extension of deadlines, authorizing local authorities to grant solar permits, doubling incentives such as "Green Incentive" (Bianca et al. 2020). As a result, the solar energy sector expects a very strong policy to get rid of the mentioned troubles.

\section{$\mathbf{5 5 \%}$ of Solar Workers Surveyed are Already Laid Off or Suffering Cutbacks \\ Companies Surveyed March 22 - April 10 Represent Nearly 34,000 Jobs}

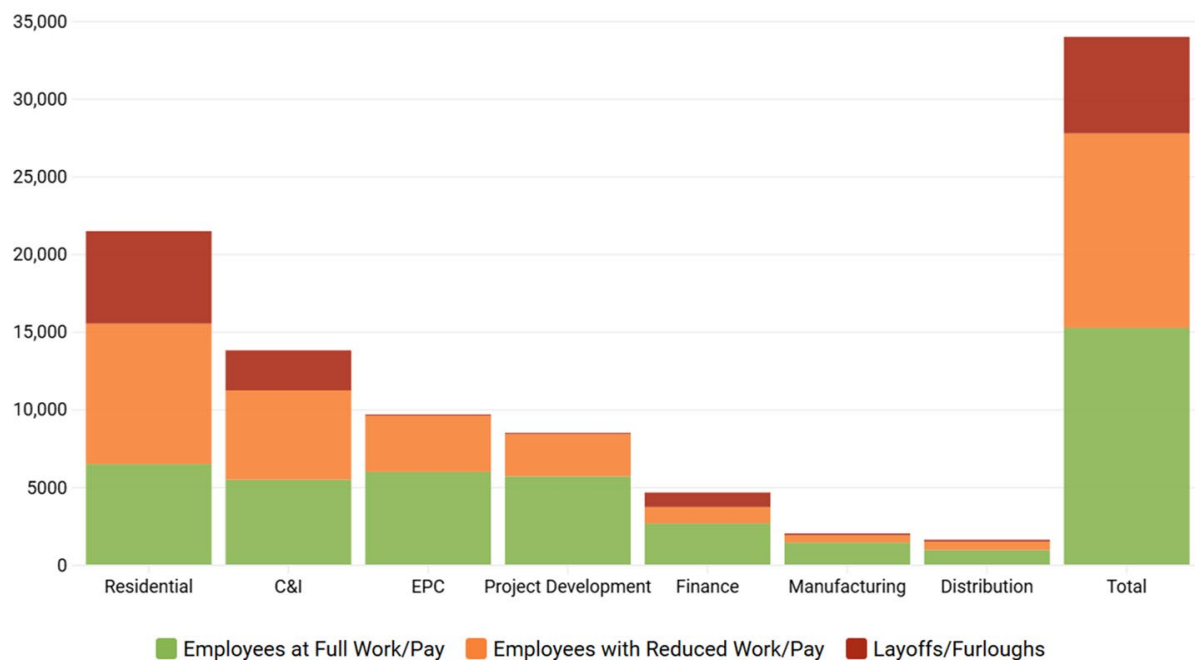

Fig. 4 Solar workers survey. $C \& I$ Commercial and Industrial, EPC engineering, procurement and construction (SEIA 2020b) 


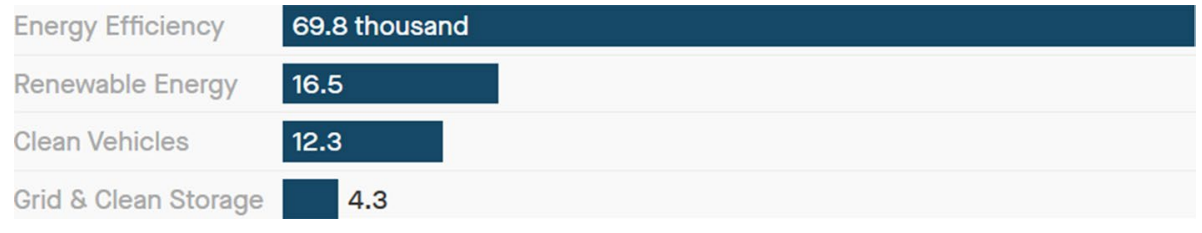

Fig. 5 Distribution of lost jobs in the clean energy sector in the USA by March 2020 (Tim 2020)

\section{Conclusions}

Worldwide, the outbreak caused by Covid-19 causes people to have limited social freedom. It causes serious environmental waste due to medical mobility in the environmental sense. On the other hand, it also leads to a decrease in household waste since people who are isolated at home are afraid of waste due to their sociological concerns. On the other hand, reductions in greenhouse gas emissions were observed due to significantly reduced road transport, reduced industrial, educational and other activities, but it was demonstrated that this was not enough to curb air pollution for all pollutants. The outbreak caused very serious problems in the renewable energy sector, such as delays in the supply chain, difficulties in tax stock markets and the risk of not being able to benefit from government incentives ending this year. Investors act unstable due to the uncertainty in the sector. Therefore, countries need to demonstrate very serious clean energy incentives. In this study, the relationship between Covid-19 outbreak, environment and renewable energy sector in a global sense was discussed and a detailed literature review was conducted that could be useful for planning further researches on the subject.

\section{References}

Anmar, F. (2020). Coronavirus at wind power plant in North Dakota shuts down production. Retrieve April 21, 2020, from https://www.cnbc.com/2020/04/20/coronavirus-at-wind-power-plant-in-north-dakot a-shuts-down-production.html.

Bandyopadhyay, S. (2020). Coronavirus disease 2019 (COVID-19): We shall overcome. Clean Technologies and Environmental Policy, 22(3), 545-546. https://doi.org/10.1007/s10098-020-01843-w.

Bianca, M., Sally, H., \& Claire, M. (2020). The impact of the coronavirus on the renewable energy industry-Center for American Progress. Centre for American Progress. Retrieve April 21, 2020, from https ://www.americanprogress.org/issues/green/news/2020/04/15/483219/impact-coronavirus-renewableenergy-industry/.

Birol, F. (2020). Put clean energy at the heart of stimulus plans to counter the coronavirus crisis-Analysis-IEA (pp. 1-4). IEA. Retrieved April 21, 2020, from https://www.iea.org/commentaries/put-clean -energy-at-the-heart-of-stimulus-plans-to-counter-the-coronavirus-crisis.

CDP. (2020). The relationship between climate change and coronavirus (Covid-19). CDP Turkey. Retrieved April 20, 2020, from https://cdpturkey.sabanciuniv.edu/tr/content/iklim-coronavirus.

Conte, M., Merico, E., Cesari, D., Dinoi, A., Grasso, F. M., Donateo, A., et al. (2020). Long-term characterisation of African dust advection in south-eastern Italy: Influence on fine and coarse particle concentrations, size distributions, and carbon content. Atmospheric Research. https://doi.org/10.1016/j.atmos res.2019.104690.

Conticini, E., Frediani, B., \& Caro, D. (2020). Can atmospheric pollution be considered a co-factor in extremely high level of SARS-CoV-2 lethality in Northern Italy? Environmental Pollution. https://doi. org/10.1016/j.envpol.2020.114465.

Contini, D., \& Costabile, F. (2020). Does air pollution influence COVID-19 outbreaks? Atmosphere, 11(4), 377. https://doi.org/10.3390/atmos11040377. 
David, M. (2020). Coronavirus 'a crisis unlike anything the market has even seen' for wind sector, Woodmac says-News for the oil and gas sector. Retrieved April 21, 2020, from https://www.energyvoic e.com/otherenergy/230431/coronavirus-a-crisis-unlike-anything-the-market-has-even-seen-for-windsector-woodmac-says/.

Doherty, B. (2020). Qantas slashes flights as coronavirus hits passenger numbers. The Guardian. Retrieved March 19, 2020, from https://www.theguardian.com/business/2020/mar/10/qantas-slashes-flights-ascoronavirus-hits-passenger-numbers.

Emma, N. (2020). Coronavirus could weaken climate change action, hit clean energy. Retrieved April 21, 2020, from https://www.cnbc.com/2020/03/13/coronavirus-could-weaken-climate-change-action-hitclean-energy.html.

ESA. (2020). Coronavirus lockdown leading to drop in pollution across Europe. European Space Agency. Retrieved April 20, 2020, from https:/www.esa.int/Applications/Observing_the_Earth/Copernicus/ Sentinel-5P/Coronavirus_lockdown_leading_to_drop_in_pollution_across_Europe.

Gautam, S. (2020). The influence of COVID-19 on air quality in India: A boon or inutile. Bulletin of Environmental Contamination and Toxicology, 0123456789, 2019-2021. https://doi.org/10.1007/s0012 8-020-02877-y.

Gautam, S., \& Hens, L. (2020). SARS-CoV-2 pandemic in India: What might we expect? Environment, Development and Sustainability, 0123456789, 2-4. https://doi.org/10.1007/s10668-020-00739-5.

Gautam, S., \& Trivedi, U. (2020). Global implications of bio-aerosol in pandemic. Environment, Development and Sustainability, 22(5), 3861-3865. https://doi.org/10.1007/s10668-020-00704-2.

Huang, C., Wang, Y., Li, X., Ren, L., Zhao, J., Hu, Y., et al. (2020). Clinical features of patients infected with 2019 novel coronavirus in Wuhan, China. The Lancet. https://doi.org/10.1016/S0140-6736(20)30183 -5 .

Jonathan Amos. (2020). Coronavirus: Lockdowns continue to suppress European pollution-BBC News. Retrieved May 16, 2020, from https://www.bbc.com/news/science-environment-52065140.

Jribi, S., Ben, H., Doggui, D., \& Debbabi, H. (2020). COVID-19 virus outbreak lockdown: What impacts on household food wastage ? Environment, Development and Sustainability, https://doi.org/10.1007/ s10668-020-00740-y.

Linton, N. M., Kobayashi, T., Yang, Y., Hayashi, K., Akhmetzhanov, A. R., Jung, S., et al. (2020). Incubation period and other epidemiological characteristics of 2019 novel coronavirus infections with right truncation: A statistical analysis of publicly available case data. Journal of Clinical Medicine. https:// doi.org/10.3390/jcm9020538.

McMahon, J. (2020). Coronavirus lockdown likely saved 77,000 lives in China just by reducing pollution. Forbes. Retrieved April 20, 2020, fromhttps://www.forbes.com/sites/jeffmcmahon/2020/03/16/coron avirus-lockdown-may-have-saved-77000-lives-in-china-just-from-pollution-reduction/\#7b3c470534fe.

McPhee, D. (2020). Moray East offshore wind project 'on track' despite Covid-19 delays, director claims. Energy Voice. Retrieved April 21, 2020, from https://www.energyvoice.com/otherenergy/235798/ moray-east-offshore-wind-project-on-track-despite-covid-19-delays-director-claims/.

Muhammad, S., Long, X., \& Salman, M. (2020). COVID-19 pandemic and environmental pollution: A blessing in disguise? Science of the Total Environment, 728, 138820. https://doi.org/10.1016/j.scito tenv.2020.138820.

Myllyvirta, L. (2020). Coronavirus has temporarily reduced China's $\mathrm{CO}_{2}$ emissions by a quarter. Carbon Brief. Retrieved April 20, 2020, from https://www.carbonbrief.org/analysis-coronavirus-has-tempo rarily-reduced-chinas-co2-emissions-by-a-quarter.

Qian, X., Ren, R., Wang, Y., Guo, Y., Fang, J., Wu, Z.-D., et al. (2020). Fighting against the common enemy of COVID-19: A practice of building a community with a shared future for mankind. Infectious Diseases of Poverty. https://doi.org/10.1186/s40249-020-00650-1.

Robert, B. (2020). Discarded coronavirus masks clutter Hong Kong's beaches, trails. Reuters. Retrieved April 20, 2020, from https://www.reuters.com/article/us-health-coronavirus-hongkong-environmeidUSKBN20Z0PP.

Rohwer-Kahlmann, M. (2020). Will the coronavirus change the way we work from home? DW. Retrieved April 20, 2020, from https://www.dw.com/en/will-the-coronavirus-change-the-way-we-work-fromhome/a-52853147.

SEIA. (2020a). Retrieved April 21, 2020, from https://www.seia.org/sites/default/files/2020-04/2020-April -SEIA-COVID-Factsheet.pdf.

SEIA. (2020b). SEIA COVID-19 industry survey. https://www.seia.org/coronavirus-information-resources.

Sharma, S., Zhang, M., Anshika, Gao, J., Zhang, H., \& Kota, S. H. (2020). Effect of restricted emissions during COVID-19 on air quality in India. Science of the Total Environment, 728, 138878. https://doi. org/10.1016/j.scitotenv.2020.138878. 
Tim, M. (2020). Covid-19 is wiping out clean energy jobs in the US-Quartz. Retrieved April 21, 2020, from https://qz.com/1840363/covid-19-is-wiping-out-clean-energy-jobs-in-the-us/.

Tobías, A., Carnerero, C., Reche, C., Massagué, J., Via, M., Minguillón, M. C., et al. (2020). Changes in air quality during the lockdown in Barcelona (Spain) one month into the SARS-CoV-2 epidemic. Science of the Total Environment, 726, 138540. https://doi.org/10.1016/j.scitotenv.2020.138540.

Wang, P., Chen, K., Zhu, S., Wang, P., \& Zhang, H. (2020a). Severe air pollution events not avoided by reduced anthropogenic activities during COVID-19 outbreak. Resources, Conservation and Recycling, 158(March), 104814. https://doi.org/10.1016/j.resconrec.2020.104814.

Wang, G., Zhang, Y., Zhao, J., Zhang, J., \& Jiang, F. (2020b). Mitigate the effects of home confinement on children during the COVID-19 outbreak. The Lancet, 395(10228), 945-947. https://doi.org/10.1016/ S0140-6736(20)30547-X.

Watts, J., \& Kommenda, N. (2020). Coronavirus pandemic leading to huge drop in air pollution (pp. 2-5). The Guardian. Retrieved April 20, 2020, from https://www.theguardian.com/environment/2020/ mar/23/coronavirus-pandemic-leading-to-huge-drop-in-air-pollution.

WHO. (2020a). Coronavirus disease (COVID-19) pandemic. Retrieved April 20, 2020, from https://www. who.int/emergencies/diseases/novel-coronavirus-2019.

WHO. (2020b). Water, sanitation, hygiene and waste management for the COVID-19 virus. Geneva: World Health Organisation.

Wilder-Smith, A., \& Freedman, D. O. (2020). Isolation, quarantine, social distancing and community containment: Pivotal role for old-style public health measures in the novel coronavirus (2019-nCoV) outbreak. Journal of Travel Medicine. https://doi.org/10.1093/jtm/taaa020.

Yu, K. D. S., \& Aviso, K. B. (2020). Modelling the economic impact and ripple effects of disease outbreaks. Process Integration and Optimization for Sustainability. https://doi.org/10.1007/s41660-020-00113-y.

Zeng, J., Huang, J., \& Pan, L. (2020). How to balance acute myocardial infarction and COVID-19: The protocols from Sichuan Provincial People's Hospital. Intensive Care Medicine. https://doi.org/10.1007/ s00134-020-05993-9.

Zhou, L., Li, F., Wu, S., \& Zhou, M. (2020). "School's out, but class's on", the largest online education in the World Today: Taking China's practical exploration during the COVID-19 epidemic prevention and control as an example. Best Evidence of Chinese Education, 4(2), 501-519. https://doi.org/10.15354/ bece.20.ar023.

Zuo, M. (2020). Coronavirus leaves China with mountains of medical waste. South China Morning Post. Retrieved April 20, 2020, from https://www.scmp.com/news/china/society/article/3074722/coronaviru s-leaves-china-mountains-medical-waste.

Publisher's Note Springer Nature remains neutral with regard to jurisdictional claims in published maps and institutional affiliations. 